\author{
Łucja PIEKARSKA-DURAJ \\ Jagiellonian University in Kraków \\ lucja.piekarska-duraj@uj.edu.pl

\section{Barbara TÖRNQUIST-PLEWA} \\ Lund University \\ barbara.tornquist-plewa@slav.lu.se
}

\title{
EUROPEANIZATION IN REGIONAL MUSEUMS?
}

\section{EXAMPLES FROM SWEDEN AND POLAND}

ABSTRACT European museums have undergone major changes in recent decades, mirroring many of the social and cultural processes taking place in Europe. Two of the main issues that have shaped the public discourse concerning cultural heritage are that of democratization and civil participation, both of which have not only mobilized policies but also redefined musealized heritage. At the same time, a 'new museology' approach, where heritage is understood as a dynamic construct, shared and interpreted by communities rather than monopolized by external authorities, has inspired many museums to rethink their visions and programs. While heritage democratization processes may be found both in the Lund and Tarnów museums, there are considerable differences between the two of them. The article examines these with the use of several concepts from core civilizational ideas such as: utility, progress, dignity, democratic governance and inclusion. In both cases, heritage is used to support the present political legacy: in the Swedish case, the emphasis is openly put on diversity and civil empowerment, whereas in Tarnów the narrative of past glory overwhelms other aspects of the past. Nevertheless, it is the European concept of the 'person' which stands behind both of them, however vague and complex its conceptualization may be.

Key words: regional museums, heritage, democratization, Europeanization 
This article examines two regional museums, the Kulturen Museum in Lund in Sweden and the District Museum of Tarnów in Poland, in order to explore to what extent their practices are related to the processes of Europeanization. The term Europeanization denotes here a multidimensional process of the transformation of European societies under the influence of European integration. It includes, as has been argued by many scholars, ${ }^{1}$ changes in the selection and interpretation of cultural heritage at the local, regional and national levels. This process is multidirectional and encompasses both the vertical and horizontal diffusion of ideas: the top-down actions of EU institutions, bottom-up initiatives of individuals and organisations, and the transnational, horizontal exchanges of ideas resulting from the intensification of cooperation at all levels of European society. ${ }^{2}$

Both Sweden and Poland are countries that became members of the EU relatively late (Sweden 1995 and Poland 2004) whilst having been members long enough to participate in the EU's politics of heritage and memory. ${ }^{3}$ Thus, it seems justified to ask to what extent the ideas of Europe and what is European heritage and memory, are to be found on the regional and local level. In other words: how is Europe present and articulated (or not) in such popular institutions as museums focused on the history and culture of a specific place?

There are several reasons which warrant the exploration of museums in studies of the Europeanization processes of heritage. First of all, they present a high level of the institutionalization of social memory while at the same time remaining dynamic lieux de mémoire, as well as - in a number of cases - constituting significant public spaces where diverse debates may be held. Secondly, museums frequently strive to support the mythological aspect of collective identities by emphasizing continuity. As such, they give a particular community (a locality, region, nation etc.) access to symbolic resources. Finally, museums themselves are much more than custodians of the past: they should also be seen as interpreters who want to have their say when various identities are constructed. Having said that, it should be emphasized that the museums of the $21^{\text {st }}$ century in Europe are - perhaps more so than ever before - experiencing significant transformations which, on the one hand, affirms their relevance but, on the other, makes researching them a quite challenging task.

1 See, for example: M. Sassatelli, Becoming Europeans. Cultural Identity and Cultural Policies, New York 2009; or C. Shore, "Inventing Homo Europaeus: The Cultural Politics of European Integration", Ethnologia Europaea. Journal of European Ethnology, vol. 29, no. 2 (1999), pp. 53-66.

2 For a general description of these processes see: K. Kowalski, B. Törnquist-Plewa, "Heritage and Memory in a Changing Europe. Introductory Remarks", in iidem (eds.), The Europeanization of Heritage and Memories in Poland and Sweden, Kraków 2016, pp. 15-32.

3 For more about this aspect see: ibid. 


\section{THE ‘NEW MUSEOLOGY’ AND EUROPEANIZATION}

In order to examine and compare the complex practices of the two selected museums from the point of view of Europeanization, we have developed an analytical framework based on studies of the processes of heritage Europeanization and the propositions of the so called 'new museology' that aims to transform museums from contemplation and presentation spaces into living lieux de mémoire. ${ }^{4}$

As pointed out by several researchers, ${ }^{5}$ the EU's politics of heritage and memory since around 2007 has evolved from the emphasis on the common contents and events in the European past to the foregrounding of common frames and modes for interpreting the past. The idea behind this change of focus is to integrate the many national perspectives that are frequently in conflict with each other into a common value framework that would make it possible for the different views on the past to co-exist without causing conflicts. Thus, in line with this politics, the past should be interpreted through the prism of values seen as historically embedded in Europe. The most important of them, such as freedom, democracy, tolerance, respect for humans, citizen and minority rights, cultural pluralism, rule of law, and democracy have been articulated in a number of the EU's documents. ${ }^{6}$ This new way of looking at European heritage has been reflected in the numerous programmes and, actions by the EU as well as in the policy documents such as the European Commission's document, Mapping of cultural heritage actions in European Union policies, programmes and activities, issued in $2014 .{ }^{7}$ It is noteworthy that as the first priority area this document mentions: cultural diversity, intercultural dialogue and accessible and inclusive culture. ${ }^{8}$

An important point that we want to make here is that the views on cultural heritage promoted within the EU, and pointed out above, are very much in tune with the ideas of the new museology which calls for making a shift from the official narratives of

The movement of 'new museology' brought changes which eventually redefined museums as public institutions in the $21^{\text {st }}$ century. By highlighting the democratic aspect of heritage, not only the traditional authority of museums (as having monopoly on interpreting the past) was questioned, but new ways of sharing collective identity were introduced, with eco-museums as models for community based, inclusive lieux de mémoire. New museology is considered to have originated, among others, from the crisis of the nation state which took place in the 1960s in Western Europe and can be symbolized by the fall of de Gaulle's rule in France. See: P. Vergo (ed.), The New Museology, London 1989.

5 For example: A. Sierp, History, Memory, and Trans-European Identity. Unifying Divisions, New York-London 2014; O. Calligaro, Negotiating Europe. EU Promotion of Europeanness since the 1950s, New York 2013; K. Kowalski, B. Törnquist-Plewa, "Heritage and Memory...".

6 For example in the Lisbon Treaty. See: "A Europe of rights and values", Treaty of Lisbon, at <http:// ec.europa.eu/archives/lisbon_treaty/glance/rights_values/index_en.htm>, 16 November 2016.

7 European Commission, Mapping of Cultural Heritage actions in European Union policies, programmes and activities, August 2017, at <http://ec.europa.eu/assets/eac/culture/library/reports/2014heritage-mapping_en.pdf>, 15 March 2017. For more examples see: K. Kowalski, B. Törnquist-Plewa, "Heritage and Memory...".

8 Ibid. 
a sacralized past towards people, participation and the intangible. ${ }^{9}$ Moreover, the new museology wants to place the person at the center of any museum's narrative and foreground the concepts such as human dignity, democratization and inclusion. ${ }^{10}$ In the domain of heritage, where fragments and remains of the past are transformed into its representations, the question of symbolic violence imposed by specific social classes is fundamental. The distribution of symbolic resources is never totally equal and in museums not all voices can be made heard in the symphonies of the past. However, according to the idea of new museology, museums can be a part of democratization processes and even promote democracy in general by striving for multivocality, instead of constructing heritage by only recreating the official discourse of the past.

A large number of contemporary museums are aware of the fact that representing the past requires the diversification of exhibits and interpretive perspectives. Yet, the diversity of testimonies of the past is often very difficult to acquire, especially when it comes to heritages of previously marginalized groups - it is much easier to illustrate the past with official documents and objects of public significance. The new museology postulates that in museums of the $21^{\text {st }}$ century the question of diversity is important and should be taken into account not only in exhibitions but also in terms of outreach for various audiences and the effective inclusion of different groups into the interpretation of musealized heritage. Thus, not only democracy, inclusion and participation, but also diversity are key words in the new museology. Also noteworthy is the attention placed by the proponents of the new museology on the question of narrativity. With the impossibility for museums to provide direct access to the past and with the limitations of museum representation, there is always a need for interpretation which comes in various forms of storytelling, as the exhibits are usually speechless on their own. Generally speaking, narrativity in museums is a way of building new senses to the exhibits and at the same time strengthening the linearity of a story, which, in turn, supports the continuity and construction of collective identity. The figure of continuity can furthermore be reinforced by the idea of (and faith in) progress, firmly rooted in European culture since the Enlightenment and narrated widely in European museums. Progress, which can be seen as a linear story directed towards a better future, need not be limited to civilizational optimism, but in fact gives meaning to all efforts of humans when they keep improving their lives. Furthermore it should be added that many museums of the $21^{\text {st }}$ century often aspire to be recognized in terms of their utility: be it civil or educational utility. They are prepared to teach, inspire and contribute to the development of a number of practical skills. Unlike in classical museums, the heritage on display in many $21^{\text {st }}$ century museums is no longer self-explanatory, being valuable only for the fact it belongs to the sacralized past which cannot be recreated. There has been a significant shift from museums as the 'temples of muses' towards more open

For more discussion about the ideas of the new museology see: G. Anderson (ed.), Reinventing the Museum. Historical and Contemporary Perspectives on the Paradigm Shift, New York 2004; as well P. Vergo (ed.), The New Museology.

10 See: Ł. Piekarska-Duraj, "Democratization as an Aspect of Heritage Europeanization. The Museum Triangle”, in K. Kowalski, B. Törnquist-Plewa (eds.), The Europeanization..., pp. 33-58. 
and inclusive institutions, with an emphasis on the profane rather than the sacred. As argued by Jean Clair, in terms of a culture without a cult, the positioning of museums has proven to be very complex. ${ }^{11}$ It could even be said that the museums of today strive to justify their raisons d'etre by pointing more or less directly to their usefulness and informing their clients and sponsors about their missions and visions. This utilitarian aspect is also very much in line with the European Union's policies regarding heritage. ${ }^{12}$ Noteworthy in this context is a correspondence between the ideas of utility in the modern museums and education. As shown above, it is one of the many ideational connections between the two.

Therefore, the juxtaposing of the main directions in the European politics of heritage, and the main ideas of the new museology, demonstrates that they are closely related. ${ }^{13}$ They display many ideational connections and overlap in regard to the values and qualities they want to foreground in heritage work. This insight has led us to identify a set of seven value-based elements which are common for the discourses of the new museology and the EU's ideas on heritage. We propose regarding them as core qualities to be used as an analytical tool, a yardstick to investigate the Europeanization of heritage in museums. These seven qualities, which we see as the bearers of certain European values and regard as indicators of Europeanization, are: progress, utility, dignity, diversity, inclusion, narrativity and democratic governance.

Thus, we suggest that scholars investigating the Europeanization of heritage in museums could consider the seven core qualities and operationalize them in the form of questions put to their material. After placing them in a specific order, one obtains the acronym of PUDDING which makes it easy to use in the research field, as all the elements can easily be re-conceptualized and also memorized by researchers during the analytical process.

\section{PUDDING: WHAT DOES IT STAND FOR?}

There is a set of issues to raise with each letter and the concept which it stands for in the acronym. ${ }^{14}$ When analyzing PROGRESS in museums, a general story line should be looked at. ${ }^{15}$ This is not to say - in terms of Europeanization - that only linear stories

11 J. Clair, Malaise dans les musées, Paris 2007.

12 See: European Commission, Mapping of Cultural Heritage actions...

13 Indeed, it should be noted that the new museology is not exclusively European, but largely a global development in heritage management. However, this just supports the argument by Gerard Delanty that Europeanization should be seen in relation to globalization. See: G. Delanty, The Cosmopolitan Imagination. The Renewal of Critical Social Theory, Cambridge 2009.

14 The concept of European PUDDING is introduced and developed in: Ł. Piekarska-Duraj, The Invisible Hand of Europe (manuscript in progress).

15 See Tony Benett's idea of museums' 'vision' as a way of conceptualizing museums for analysis in: T. Bennett, "Civic Seeing: Museums and the Organisation of Vision", in S. MacDonald (ed.), A Companion to Museum Studies, Hoboken 2011, pp. 236-281. 
can be considered European: other models of storytelling are also present in European museums, with multivocality perhaps the most democratic one. Yet in museum narratives, progress could be found in most general attitude of the present to the past and especially in their particular abilities to grasp social change.

In terms of the UTILITY of museums' visions, missions and activities should be focused on, with special attention given to what they teach (in terms of competences, skills), but also if they involve some kind of public mission (for example, in promoting tolerance and appreciating differences) or are active local players. With museums' analysis, the point of utility is to be useful, not only to prove the symbolic significance in conserving the past. ${ }^{16}$

The third element of the framework is DIGNITY, with the concept of the person, human rights and free will at its heart. Research concerning this idea should comprise a closer look at the ways individuals are presented in a museum, but also if any sensitive heritage is dealt with care. With sensitive heritage, the question is actually more significant than 'paying respect to ancestors', because - as strengthened by the complimentary rules of progress and of continuity - the museums' audiences should also feel respected in their private and individual approaches. Dignity can be most evidently traced when any remains of human bodies are musealized and the question of the necessity of such public burial arises.

To comply with the logic of individual value, another indicator of Europeanization should be examined and that is the value of DIVERSITY - clearly present in the EU's programmatic motto 'Unity in Diversity'. Diversity ${ }^{17}$ can be first of all operationalized in museums when referring to: objects and exhibits; narrative strategies and storytelling; audiences and other client groups - especially in terms of their participation in museum's activities. Since the diversity of the presented past can be defined as the opposite of monolithic and univocal, when one addresses this issue in museum research, ${ }^{18}$ the main point would be to look at the complexity of the presentation of the past: in terms of class and gender representations as well as other minority narratives. ${ }^{19}$ The latter is also an indicator of INCLUSION, the next element of the analytical framework presented here. Inclusion could be regarded in its relation to the unique value of an individual and his/her abilities to comprehend the heritage on display, but at the same time an inclusive exhibition would be one where unofficial and marginalized heritages are present and audiences are encouraged to participate in interpreting the museum's messages..$^{20}$ As mentioned already, museums operate within certain limits of represen-

16 On the influence of the Enlightenment ideas on heritage in museums see: M. O’Neill, “Enlightenment Museums: Universal or Merely Global?", Museum and Society, vol. 2, no. 3 (2004).

17 The issue of diversity in relation to exhibiting particularities and cultural systems was thoroughly discussed by Tony Benett in: T. Bennett, "Exhibition, Difference, and the Logic of Culture", in I. Karp, C. Kratz, L. Szwaja (eds.), Museum Frictions. Public Cultures/Global Transformations, Durham 2006, pp. 46-69.

18 See: D.J. Sherman, Museums and Difference, Bloomington 2008.

19 See: T.W. Luke, Museum Politics. Power Plays at the Exhibition, Minneapolis 2002.

20 See: R. Sandell (ed.), Museums, Society, Inequality, London 2002. 
tation. Therefore, interpretation (of objects and intangible heritages) is a crucial factor when it comes to giving access to the resources of the past by museums. Museums not only store and produce numerous stories but also take part in creating heritage and thus public discourse in general.

NARRATIVITY, which is another element in the PUDDING framework, should be researched in relation to all of a museum's discursive practices, with storytelling as the most obvious one. The main questions would be: whose stories are told, what is the narrative perspective of the museum (is it striving to be transparent or rather subjective) and - last but not least - how successful museums are in helping to set relations between the visitors and heritage. Narrativity, ${ }^{21}$ as the potential to interpret objects by telling stories, compliments the value of progress and the general time model structured for representation purposes in museums, as well as revealing if visitors are actually able to create their own stories by identifying with some aspects of heritage on display. Another perspective to discuss narrativity can be found in mission statements, where museums often aim to present themselves as either interpreters or neutral transmitters of the past.

What can be seen as the cherry on top of the PUDDING model is the question of democratic GOVERNANCE, understood both as a way of influencing the contemporary political scene and reflecting a museum's way of narrating the power relations of the past exhibited. ${ }^{22}$ This element of analysis is also directly connected to the problem of utility, as it shows how museums answer the needs of providing their visitors and communities with opportunities to develop civil competencies. Another aspect of governance which can be analyzed is the museum's involvement in local affairs, be it by creating unique outreach programs for local communities or catalyzing local initiatives. This is also an effective way of interpreting museums' political programs and ideologies, both performed publicly and on the backstage. The question of democracy is essential in this case, finalizing the whole set of research issues by examining from an ideological perspective the problems of: inclusion of audiences and minority narratives, opportunities for participation, equality in representation and - again - the notion of integrity of a person, as a key concept to the logic of democracy.

In the following we will use the proposed analytical model of PUDDING to investigate two regional museums, the Museum of Cultural History and Open-Air Museum in Lund called Kulturen in Sweden and the Main Building, located at the Town Hall, a branch of the District Museum in Tarnów in Poland. In our view, such a comparison can broaden the horizon of reflection on the processes of heritage Europeanization in museums and, at the same time, give us the opportunity to test the new analytical tool, described above.

21 The discursive practice in relation to history creation was presented among others in: D.J. Sherman, I. Rogoff (eds.), Museum Culture. Histories, Discourses, Spectacles, Minneapolis 1994.

22 It is very useful in this context to use Michel Foucault's theory where the notions of inclusion and inclusions are revealed in their relation to the power systems. See: B. Lord, "Foucault's Museum: Difference, Representation and Genealogy", Museum and Society, vol. 4, no. 1 (2006). 


\section{THE KULTUREN MUSEUM IN LUND}

Kulturen is the second oldest open-air museum in Sweden and probably in the world. It was opened in 1882, just one year after Skansen in Stockholm, the model for other open-air museums in Europe. ${ }^{23}$ The founder of Kulturen and the managing director until 1933 was, Georg Karlin. Like Arthur Hazelius, the founder of Skansen, Karlin was influenced by the ideals of national romanticism. He observed the gradual disappearance of the old farming society in Southern Sweden and wanted to preserve its traces for posterity and also wished to rescue objects from the medieval period in Lund. ${ }^{24}$ Therefore, the museum he created was destined from the beginning to function both as a regional museum and the local museum for the city of Lund.

The main part of Kulturen is located near the historic Lund cathedral in central Lund. The museum consists of a number of exhibitions mounted in several buildings and an open-air museum which was built according to the pavilion system, inspired by the international exhibitions of the $19^{\text {th }}$ century. It includes over 30 different buildings, most of them moved from the different parts of the city and the countryside, originating from different epochs, from the Middle Ages to the 1930s. Around the houses there are street settings and gardens. ${ }^{25}$ Kulturen has a large and unique collection of more than two million items. The visitor can choose from among twenty exhibitions - from folk art to modern design, from medieval history to the present day, from local culture to world culture.

With the proposed analytical framework of PUDDING, we approached Kulturen in order to trace the signs of the Europeanization of heritage in the museum's activities and exhibition. We analyzed a number of documents where the vision and mission of the museum is formulated, the exhibitions and, last but not least, Kulturen's work with visitors and outreach in general. The methods applied were: content analysis, close reading of the museum's policy documents, visual analysis of exhibitions, participant observation and interviews with some of the employees (director, former director and communicator - responsible for PR).

23 For more about Skansen see the contribution by $€$. Bukowiecki in this volume.

24 In the 1890s, when the city dug its first sewers, he began to collect the finds from the excavations. At several places in the open-air museum the visitor can see fragments of medieval buildings, chiefly from demolished medieval churches in Lund. There is a large concentration of these in the Lapidarium.

25 In the 1920s, thanks to a generous donation, Karlin was also able to acquire a farm in Östarp, east of Lund, where he created a museum in the middle of the existing cultural landscape. Besides this, the visitor can experience other places, included in the museum: Hökeriet, which is the oldest grocery store in Lund, the Museum of Life (Livets museum), which is about the human body functions, and the Museum of Medical History in Helsingborg. 


\section{THE MISSION AND VISION OF KULTUREN}

Kulturen was founded under the auspices of the nonprofit organization called the Cultural-Historical Association for Southern Sweden (Kulturhistoriska föreningen för södra Sverige) which until today is the museum's main administrator. The association, the regional government of Scania and the Lund municipality share the costs of the museum (one third each). The main mission for Kulturen is expressed in the statutes of the association which state that its goal is to collect and preserve the tangible cultural heritage with special focus on southern Swedish cultural history and in connection therewith promote research and education as well conduct activities related to these tasks. ${ }^{26}$ The other two principals of the museum, the regional authorities and municipality, add to this main mission some more specific duties formulated in special documents. Thus, the regional authorities want the museum to develop international contacts but, first and foremost, to work actively with 'accessibility, ${ }^{27}$ with a particular focus on children, youth and national minorities. The idea of accessibility as a part of a policy of inclusion is also emphasized in the documents formulating the tasks assigned to Kulturen by the Lund municipality. In connection to the concept of inclusion the city encourages the museum to promote 'hospitality. ${ }^{28}$ Additionally, as an important undertaking for Kulturen, the city highlights the need to work with 'sustainable development', including economic development and tourism. It points to the utilitarian aspects in heritage work.

Values such as democracy and inclusion have been vitally important for Kulturen's work for many years, which is evidenced in the museum's annual reports. ${ }^{29}$ However, in 2016, the museum found it necessary to adopt a special policy document called Kulturen's Värdegrund (Kulturen's Principal Values in our translation). This was due to the museum's controversies with non-liberal actors such as the Embassy of Iran and the nationalist party Swedish Democrats that were denied the opportunity to rent the museum's conference facilities. In this context, the museum wished to make its ideological position clear.

Consequently, the document Kulturen's Principal Values declares that Kulturen is firmly grounded in such values as democracy, equality, diversity, accessibility and equal value of each person and that it wants to contribute to open and democratic society which affirms diversity. Additionally, the museum wants to contribute to social cohesion and

26 See the statutes: Föreningens stadgar, Kulturen, at <https://www.kulturen.com/om-kulturen/ vardegrund-vision-och-uppdrag/foreningens-stadgar/>, 21 February 2017. Translation from Swedish made by the authors.

27 See Kulturen's official document Principal Values, Mission and Vision: Regionalt uppdrag, Kulturen, at <https://www.kulturen.com/om-kulturen/vardegrund-vision-och-uppdrag/regionalt-uppdrag/>, 21 February 2017. Translation from Swedish made by the authors. Ibid.

29 For the annual reports see: Kulturens verksambetsberättelse 2015 (Kulturen's annual report from 2015), at $<$ http://online.pubhtml5.com/lbgr/etzh/\#p=4>, 1 March 2017. This was also stated by the museum's communicator Johan Hofvdahl in the interview conducted 16 March 2016. 
creation of a society where everyone feels included and welcome. It is even stated that we have courage and dare take a position on issues relating to human equality and further: In the matter of cooperation and business relations Kulturen should not have any connection with the parties or representatives of the parties whose values conflict with the values of Kulturen. This does not prevent us to initiate or contribute to activities that include or may include dialogue with such parties. ${ }^{30}$

This policy document discloses that Kulturen is involved in the ideological struggles at play in Sweden and elsewhere in Europe and that it wishes to take a stand in terms of the values emphasized by the EU. In light of that, it can be argued that on the level of discourse present in the museum's policy documents, Kulturen implements values, declared as 'European' in the EU's documents. The question is how it is translated to the museum's activities, its exhibition and work with outreach.

\section{EXHIBITIONS}

At the time of conducting our field study at Kulturen (February-March 2017), the museum had fifteen so-called 'base exhibitions' (more or less permanent) and five temporary ones. The permanent exhibitions as a whole tell a story about how people of all social layers lived in villages and towns in southern Sweden, especially Scania, from the early medieval period until around the middle of the $20^{\text {th }}$ century. Everyday life and work is emphasized and some focus is put on Lund's history as a dynamic center of ecclesiastic, scientific and artistic life in this part of Europe. Thus, it is first and foremost regional and local heritage, and not the national one, that is foregrounded and the accent is on the region's and city's contacts with neighboring European countries, especially Denmark (to which the region belonged until 1658) and Germany.

In its promotional materials, the museum promises to take the visitor on a journey through time. ${ }^{31}$ For this purpose, the exhibition narratives are structured in linear way, irrespective of the topic: glass or ceramics, toys, textiles, weapons, foods or agricultural tools. The visitor follows the development of different objects or phenomena in chronological order. In this linear narrative the idea of progress as an unquestionable value comes forward. This is especially striking in the exhibition on the history of the book, starting with papyrus and ending with e-books as well in the exhibition on the history of Lund University. The exhibitions express a pride in human progress and the local contribution to it in the form of scientific inventions, for example a dialysis machine. It is also noteworthy that the museum educators emphasize the contrast during the guided tours between then and now to the disadvantage of the past. The past often stands for poverty, dirt, diseases, hunger, injustice and very hard work while the modern time

30 See: Kulturens värdegrund (Kulturen's Principal Values), Kulturen, at <http://www.kulturen.com/ wp-content/uploads/2017/01/Kulturens-v\%C3\%A4rdegrund.pdf>, 1 March 2017.

31 This is stated in the majority of Kulturen's information booklets. 
brings the promise of welfare, a high level of hygiene and health care, medical inventions and democratic society. ${ }^{32}$

The stories about life in the past are often told from the perspective of the individuals that lived in the buildings preserved at the open-air museum, which appeals to the visitor's imagination and enables their identification with people from the past. However, the specific persons or families described are not important in themselves as real figures that existed, but as representatives of groups and examples of the way of life. In some cases even stories about fictitious figures are created for the same purpose. There are no heroes in the presented narratives. Thus, groups and collectives seemed to be more important than individuals. The value of dignity is mostly connected to groups and their work. The exhibition presenting how folk crafts have inspired modern professional artists can serve as an example in this respect. In this exhibition it is the folk artist that is acclaimed, not any famous professional designer. Special attention is paid to the need of the folk craftsmen to put their name, initials or special marks on their work. The folk artist is compared here with the professional artist and recognized as equal in its creativity, skills and human desire to leave a trace behind and be remembered. This kind of representation: dignifying a folk artist and equating her or him with the professional one, seems to be in line with the egalitarian ideas firmly rooted in Swedish society, ${ }^{33}$ and reminds one about equality as an important value stated in museum policy documents.

Furthermore, it should be pointed out that Kulturen cherishes diversity. The museum offers a great diversity of objects and milieus on display: archeological findings, agricultural and fishery tools from different epochs, all kind of textiles, folk craft, kitchen utensils, glass, ceramics, books, printing machines, toys etc. Moreover, temporary exhibitions can contain paintings, photographs, video recordings and other art objects. The museum also presents a great variety of buildings and interiors: farm buildings from different parts of Southern Sweden, a vicarage, church and city houses. However, it is more important to highlight the fact that from its very inception Kulturen had ambitions to show the lives of different social groups and classes. In 1882 it was mostly about settings from the four estates - the nobility, the clergy, the burghers, and the peasants into which the Swedish Parliament was divided before 1866. Later on, the representations of the living conditions of other social groups were added: Professor Thomander's house (representing intellectuals/middle class) and a worker's family house from the 1930s.

Besides showing social and economic diversity, the museum cares for paying attention to the gender aspects of narratives in its exhibits. Thus, for example, the exhibition about peasant life in Scania from the $17^{\text {th }}$ to the $19^{\text {th }}$ century makes the work of women on the farm salient and tells in details about women's life, their health problems, child care, role in the economy etc. Furthermore the exhibition on Lund University's history points out how late the women were allowed to study at the university level and how

32 Observations done during such a tour on 16 March 2016, confirmed in the interview with Björn Magnusson Staaf former manager at Kulturen, conducted 24 March 2017.

33 As pointed out by J. Frykman, O. Löfgren, Den kultiverade människan, Lund 1979. 
much the life of female students differed from their male peers. Also, female folk craft is especially celebrated at Kulturen in the form of displays of beautiful woven rugs, embroideries and hand sewn cloths.

Diversity as a value is also expressed in the exhibitions that show how the culture of this part of Sweden was influenced by impulses coming from diverse cultures. Danish culture is obvious in this context since the region of South Sweden belonged to Denmark for centuries. Yet, the exhibitions also demonstrate other influences such as Italian (glass production), Chinese (ceramics) and first and foremost German (production of glass and ceramics, weapons, influence in science, higher education and arts). Additionally, the exhibition about Modernity underscores the fact that the artists from Lund got their inspiration from Berlin, Paris and Vienna and that they themselves influenced European trends in design and architecture at the end of the $19^{\text {th }}$ and beginning of the $20^{\text {th }}$ century.

However, in regard to representations of minorities, not much is to be found in Kulturen's permanent exhibitions. Indeed, in the newest permanent exhibition, the one about Modernity, the existence of sexual minorities is made visible to some extent in the connection to the interpretation of few paintings by the famous Swedish artist Gösta Adrian Nilsson (called GAN), who lived as a homosexual. Nevertheless, the representations of national or ethnic minorities are conspicuous in their absence. On the one hand, it may be not surprising since Sweden until the World War II was relatively homogeneous in terms of ethnicity, with the exception of the Sami people living in the north, small groups of Roma spread over the country and small groups of mainly Jewish immigrants (who were allowed to settle in Sweden as late as at the end of the $18^{\text {th }}$ century). On the other hand, over the last 70 years or so, the migrants continued to come to Sweden in smaller and larger waves and changed Swedish society, including that of southern Sweden and thus one may wonder why the narratives about them are missing.

The exception from this silence about minorities and migrants constitutes the exhibition To Survive - Voices from Ravensbrück which is based on witness stories and small objects submitted by a group of Polish and Jewish women who came to Sweden 1945 from the German concentration camp in Ravensbrück thanks to the rescue action conducted by the Swedish Red Cross. Many of them chose to stay in Sweden after the end of the war. The exhibition was opened 27 January $2005^{34}$ and should be seen as a part of the interest in the history of Holocaust that awoke in Sweden shortly after the country became member of the EU. ${ }^{35}$ Sweden joined (and even became a leader of) the EU's politics of memory in regard to Holocaust remembrance, seen by the EU as a tool to promote democratic values and prevent racism and nationalism. ${ }^{36}$ These educational

34 The exhibition can also be seen on the web: To Survive - Voices from Ravensbrück, Kulturen, at <http://ravensbruck.kulturen.com/English/r1.htm\#>, 3 March 2017.

35 See: B. Magnusson Staaf, "The White Buses Creating Remembrance of the Second World War in Sweden”, in K. Kowalski, B. Törnquist-Plewa (eds.), The Europeanization..., pp. 163-188.

36 See: B. Törnquist-Plewa, "The Europeanization of the Memory and Heritage of the Second World War and the Holocaust in Sweden", in K. Kowalski, B. Törnquist-Plewa (eds.), The Europeanization..., pp. 133-162. 
and ideological goals of the European politics of memory correspond well to Kulturen's own motivation for opening the exhibition, as expressed in the following statement: Among the millions of items in our vast collection of cultural history, we have now chosen to bring forth these artifacts. We do so, because it is needed. Presently, in Sweden racism has been on the rise. Islamophobia, anti-Semitism, homophobia are increasing. Have we not learned anything from history? We see what developed then! Don't we see what is happening now? ?37 $^{37}$

It is noteworthy that the museum uses the local connection to the history of the Holocaust for educational purposes, but omits at the same time sensitive questions concerning the local society's all too often positive attitudes to German Nazism in the 1930 s as well anti-Semitism in this period. ${ }^{38}$ It seems that the museum avoids being too provocative in their choice of topics. ${ }^{39}$

Nevertheless, it can be argued that the exhibition To Survive - Voices from Ravensbrück was groundbreaking since it was the first time Kulturen dealt with the narratives reflecting the experiences of non-ethnic Swedes living in the region. Later on, other attempts were made to fill this gap and thus, in 2015, the temporary exhibition Cultural history of Roma people in Sweden was set up ${ }^{40}$ and in 2016 the temporary, photography exhibition called Voices of Roma people. It consisted of a series of large photographs of individuals from different Roma groups living in Sweden. Each photograph was followed by a short, personally told life story of the person depicted. In this way, the dignity of the presented persons was emphasized and at the same time the visitors were given an opportunity to come closer to the Roma people as individuals, not just frequently stereotyped group members. This focus on Roma should be seen, in our view, in the context of the EU member states special commitment towards promoting Roma inclusion since 2011. In May 2011, the European Commission adopted an EU Framework for National Roma Integration Strategies, ${ }^{41}$ that has been followed up by recommendation for member states and a number of measures with the goal of improving the situation of Roma in Europe.

According to the information acquired in the interviews with the museum staff, the question of the representation of minorities first emerged as being very important in re-

37 See: the introduction by Margareta Alin, the director of Kulturen in the guide book for teachers, produced specially for this exhibition in 2006: Att överleva. Röster frän Ravensbrück. En lärarhandledning, Kulturen 2006, at <http://www.kulturen.com/wp-content/uploads/2016/12/Ravensbruck_ Lararhandledning.pdf>, 3 March 2017.

38 There is research made about the topic which could be used for that purpose. See: S. Oredsson, Lunds universitet under andra världskriget - motsättningar, debatter och hjälpinsatser, Lund 1996.

39 Interview with Johan Hovfdahl.

40 Världen på Kulturen, Kulturen, at <http://www.kulturen.com/utstallningar/kommande-utstallningar/ varlden-pa-kulturen/>, 10 May 2015.

41 See the document: European Commission, Communication from the Commission to the European Parliament, the Council, the European Economic and Social Committee and the Committee of the Regions "An EU Framework for National Roma Integration Strategies up to 2020”, Brussels, 5 April 2011, $\operatorname{COM}(2011) 173$ final, at <http://ec.europa.eu/transparency/regdoc/rep/1/2011/EN/1-2011-173EN-F1-1.Pdf>, 10 March 2017. 
cent years. In the view of our informants, it can be interpreted as a kind of Europeanization, but not in terms of following some policies, recommended by the EU. They rather interpret this new direction as a reaction to several processes including: an increased number of foreign visitors due to the radically increased mobility in Europe (including Roma people), the large waves of migrations that reached Sweden first after the EU-enlargement to the East and later in the wake of the latest wars in the Middle East and, last but not least, the need to counteract the nationalist forces that grown in strength in the Swedish society. Europeanization means to our informants ${ }^{42}$ being more influenced by what happens in European countries, to be involved in the problems of Europe and attempts to handle them by following values seen as European.

In recent years many museums in Europe have begun to focus on the need to represent migration and to contribute to the integration of newcomers. ${ }^{43}$ Kulturen took the first steps in this direction in 2015 by joining a major action in southern Sweden that aims at gathering testimonies by refugees who have come to Sweden since World War II to the present, and who are willing to be recorded and tell their stories of flight and exile. The idea is to collect a large database in order to preserve these refugee memories for posterity. At the end of 2016, Kulturen presented a selection of these recorded testimonies as part of the temporary exhibition entitled The World on Fire.

\section{OUTREACH}

The question of diversity is very much connected to the question of inclusion. As stated above, minority narratives are represented rather marginally in today's exhibitions in Kulturen, although the museum is taking steps to remedy this. More could also be done to encourage members of migrant communities as well foreign visitors in general to come to Kulturen. The museum staff intensified its work with this task recently and it is now even inscribed in the policy documents. According to the staff members the focus on minorities and migrants may be interpreted as a form of Europeanization. ${ }^{44}$ However, they are at the same time eager to point out that inclusion has always been important for their work. Kulturen states on its website: Our vision is to become the most vibrant and engaging museum - a role model when it comes to participation. ${ }^{45}$

In line with this vision, no costs were spared to increase accessibility for handicapped persons. Lifts were installed, wherever possible, and special appliances and facilities were created for persons with impaired hearing and vision. Special efforts are be-

42 Interview with Johan Hovfdahl, and interview with Anki Dahlin (director) conducted 5 April 2017.

43 See: "New Publication: Museums, Migrations and Cultural Diversity", NEMO, 30 May 2016, at <http://www.ne-mo.org/news/article/nc/1/nemo/new-publication-museums-migrants-andcultural-diversity>, 10 March 2017.

44 Interview with Johan Hovfdahl, as well with Björn Magnusson Staaf.

45 Official site of Kulturen: Föreningensstadgar, Kulturen, at <https://www.kulturen.com/om-kulturen/ vardegrund-vision-och-uppdrag/foreningens-stadgar/>, 21 February 2017. 
ing made as well to attract children and youth to come to the museum. Each year, a new temporary exhibition is created especially for children designed to encourage them to play and learn at the same time. Furthermore, the museum has a well-developed cooperation with schools that are offered special programs every year. Teachers can attend short courses which are given regularly, (called a 'driving license' at Kulturen) and which enables them to use the museum exhibitions in their teaching. Thus, both children from preschools as well school classes are frequent visitors. Other groups targeted by the museum are researchers and university students, particularly those who study ethnology, archeology, history and art as well foreign students taking courses about Swedish culture and society. The visits to Kulturen are included in their curriculum and such visits are also a part of Swedish language courses for migrants, who come to Kulturen with their language teachers. All of the groups mentioned above are highlighted as core audiences and main targets for Kulturen. ${ }^{46}$ However, according to the visitor studies conducted regularly by the museum, a typical visitor to the museum is a well-educated woman between 50 and 70 - a figure termed in the Swedish cultural debates as a 'Culture Auntie', since she has been statistically identified as a primary consumer of so called 'high culture'. Kulturen wishes to change this pattern. ${ }^{47}$

To promote participation also means to invite audiences to influence the activities of the museum and to relate to the contents of the exhibitions. During the preparation of the exhibitions, the staff makes efforts to invite stakeholders to discuss the content. For example, in connection to Voices from Ravensbrück a focus group was created consisting of, among others, of the few still living survivors as well representatives of both Jewish and Polish associations. ${ }^{48}$ The stakeholders have their say but the final decision about the exhibition design belongs to the museum staff. ${ }^{49}$ The only exception from this rule is the exhibition presenting the history of Lund University which was wholly created by the Society for the Studies of History of Lund University (Universitetshistoriska Sällskapet). Nevertheless, museum visitors can get insights into how the staff work with selection and interpretation, since these matters are presented on the regularly written blog on the museum webpage, as well in the Yearbook published by Kulturen.

When the exhibition is in place, visitors are invited to comment. For example, at the temporary exhibition The World on Fire (Världen brinner) the visitors have been encouraged to record their comments using the equipment which is available there. At another (about different building techniques through time), they can write their remarks on small pieces of paper. Furthermore, Kulturen works actively with social media, encouraging visitors to comment on Facebook, Twitter or Instagram. The visitors are also asked to complete short questionnaires prepared by the staff about their impressions

46 Interview with Anki Dahlin.

47 Interview with Johan Hovfdahl.

48 For more about this, as well about the exhibition in general, see: K. Tinning, "To Survive Ravensbrück: Considerations on Museum Pedagogy and the Passing on of Holocaust Remembrance", Museum \& Society, vol. 14, no. 2 (2016), pp. 338-353, at <https://www2.le.ac.uk/departments/museumstudies/museumsociety/documents/volumes/tinning>, 15 August 2017.

Interview with Björn Magnusson Staaf. 
from the visits. However, the general result of these efforts is far lower than the museum staff would hope for ${ }^{50}$ as it seems that the visitors are not so keen to give feedback. Does it mean that they are just consumers and not 'prosumers' (producers and consumers at the same time)? We should not jump to such conclusions since it has been noticed that the visitors actually share their interpretations and impressions from the visit at Kulturen with others on social media, but not so much with the museum staff. ${ }^{51}$

Also taking into account the profile of Kulturen's visitors it seems that Kulturen's primarily function is to teach and deliver knowledge about the regional and local past. This is also emphasized in the previously mentioned policy documents stating that the museum's goal is to preserve and take care of the local and regional heritage and to make it accessible for research, education and to a broader public. However, our interviews with the employees showed that the staff members do not want to limit themselves to the role of educators. They also wish to deliver pleasant experiences and even some form of entertainment (or rather infotainment) to the public. The work with intangible heritage provides opportunities in this direction and thus Kulturen regularly organizes celebrations of traditions connected to Advent, Santa Lucia, Christmas, Epiphany, Easter and Midsummer festivities that attract many people, especially families. During the summer season, the museum also invites musicians to give concerts or to play live traditional folk music for dancing. The entrance to the museum is free at these occasions and the events are really well-attended. On specially agreed dates some of the museum buildings can also be used for weddings, attracting people that do not usually come to Kulturen.

Additionally, it appears from the interviews that the museum staff wants Kulturen to be more engaged in public matters and work actively for an open, democratic society. The museum has conference facilities which can be rented by different organizations and institutions and the museum also uses it from time to time to organize small symposia or discussion panels on the urgent social questions in cooperation with other stakeholders. Another, interesting initiative in this context is Kulturen's promotion of ecumenism and religious tolerance by opening every summer the old church (one of the objects in the building collection) for the celebration of masses and prayers for all kind of Christian communities in the town. Every Sunday during the summer, one of the churches invites people to pray according to its rules and uses the opportunity to present itself.

\section{THE TARNÓW MUSEUM}

Tarnów is a medium sized town in the Małopolska region of southern Poland. It has a historical city center, with some Renaissance buildings, an interesting cathedral and the spectacular remains of the local synagogue, where nowadays artistic events are some-

\footnotetext{
50 Interview with Johan Hofvendahl.

51 Interview with Björn Magnusson Staaf.
} 
times held. For visitors, the monuments are surprisingly beautiful (although scarce) and the atmosphere seems relaxed. The District Museum of Tarnów could be seen as the guardian of the city's symbolic resources, supporting the construction of local identity and striving to define the regional one, too. For the one-day visitor, Tarnów is a charming place, but unpromising in case of a longer stay, with the museum as a must see. Feeling like a museum visit, the tourist would be naturally led to the main branch of the museum as it is situated in the town hall, a landmark of the city located in the middle of the main market square. But he or she would in fact have more options as far as museums go - there is a choice between the Archdiocesan Museum or other branches of the District Museum, for instance the Ethnographic Branch which devotes its permanent exhibition to the Roma.

The history of the Tarnów Museum proves its strong links with the history of the city of Tarnów and the region, which - influenced by political changes - might be seen as a lens for identity changes in Poland. Founded in 1927, not long after Poland regained its independence (1918), it originated from the spirit of safeguarding valuable representatives of the past that otherwise might have been lost. Tarnów, together with its museum, felt a strong mission to be a leading provincial museum and an example to other institutions of the kind nationwide..$^{52}$ In the two inter war decades the city of Tarnów developed, largely due to the decision to establish important industrial plants there (Azoty). Following its economic development, Tarnów's museums grew in splendor and the Town Hall was designed to be the main branch housing the marvels of the collection. The choice was backed up by museologists, who appreciated the collection of the city and formally suggested the town hall should change its primary function..$^{53}$ After the horrors of World War II, the new era of Tarnów Museum began. Guards were provided to keep the exhibits safe already in 1945 and, during the overwhelming postwar chaos, a new challenge of gathering art objects which had been kept at manors and in the villages, began. In this way the museum can be seen as carrying traces of the many historical changes that Poland has gone through, including the reforms introduced under communism (up to 1989) and the re-organization which followed the reforms of 1989. While today the museum may not be seen as the most relevant identity framework by the citizens of Tarnów, it certainly sees its mission in connecting them with the local past. Yet, as it will be discussed below, the gap between the past and the present is not very efficiently bridged, so the heritage on display in the Tarnów Museum is not very representative for the city itself.

In the Town Hall, the main building of the District Museum, whose exhibition will be the main focus of this analysis, the story of the past is told mostly with a strong emphasis on its splendor, significance and glory while at the same time neglecting the class diversity of heritage by focusing primarily on the legacy of noble families. In gen-

52 As noted by the delegates of the Association for Polish Museums in 1925. See: M. Piotrowski (ed.), Pamiętnik V Zjazdu Delegatów Związku Muzeów w Polsce odbytego w Tarnowie w dn. 12-13 czerwca 1930, Kraków 1930.

Ibid. 
eral, Tarnów is presented as a 'private city', a concept rather vaguely explained as a 'city owned by the Tarnowski family', and then ruled by the Sanguszkos. ${ }^{54}$ From the beginning of the museum, which was first opened as a town museum in 1927, the institution may be regarded as primarily safeguarding what is seen as historically valuable. The value - as it will be proved later on - could be seen as corresponding to the official discourse and strengthening the political legacy of the town - establishing its foundation myth within an aristocratic family genealogy.

While at present the museum consists of ten branches dispersed all over Tarnów, it is the municipal perspective of a provincial town that sets the main perspective for the interpretation of all of them. It is also the museum main building - the Town Hall that has the most recognizable and significant collection, originally mainly owned by the Sanguszko family. While in this analysis the narrative as well as the activities of the Town Hall exhibition will be covered, it should be noticed that the museum itself has nine other branches, and they cover a large scope of the region's heritage including topics such as history of the peasant movement or the town's history. Yet, most of them are strictly connected with monuments they are located in. A good example of a topical collection can be found in the medieval castle of Dębno, the painted village of Zalipie (a village with a tradition of painting house exteriors in floral patterns) or the manor of Dołęga (especially significant for $19^{\text {th }}$ century events, such as the uprisings). Considering the exhibitions of all the branches, it could be noted that the diversity of themes, topics and periods represented in the collections is vast, yet this richness can only be appreciated when the whole organization of the museum considered. When taken all together, the ten branches speak a lot about the diverse aspects of the region's history. It is very unlikely, however, that they would all be visited by one visitor, so the usual viewpoint of the visitors would be based on sightseeing having taken place in just one building. The fact that all the branches are part of one regional museum, run by regional Marshal's Office of Małopolska, was mainly an effect of the political decisions taken after 1989, when Poland entered the post-communist era and not for any content related reasons. 55

\section{THE TOWN HALL EXHIBITION IN TARNÓW}

The Town Hall exhibition is chosen to be presented here for several reasons. First of all it is, as we will argue, a good example of heritage constructed as a class attribute, relating to noble classes, although the seat of the collection may be seen as surprisingly set in the most civil of public spaces - the town hall. Secondly, the narrative of the foundational

54 The notion of the 'private city' was developed in an interview conducted with Janusz Koziol, the programme director of the Tarnów Museum, during the research project "The Europeanization of realms of memory and the invention of a common European heritage".

55 M. Kołodziej et al., "Historia Muzeum Okręgowego w Tarnowie. History of Tarnów Museum", in 80 lat Muzeum w Tarnowie. 80 Years of Museum in Tarnów, Tarnów 2007. 
myth of Tarnów is told in the most straightforward way here establishing the story in the gentry driven glory of the past times. Finally, as will be pointed out, individualism and human dignity are present in the exhibition in a very significant way reflecting the general vision of the past as shaped by the museum.

In general the foundational myth of Tarnów may be seen as the overwhelming narrative, although it is not revealed as the main theme of the Town Hall exhibition, yet the more thorough analysis reveals the narrative tells in fact more about the nation than Tarnów or the region. The narrative is constructed as a provincial town's input to the grand historical narrative, mainly the one of the nation, but - as we will argue - the reference framework of Europe is present, too. Such a construct may be explained as an attempt to valorize Tarnów and make its role significant while at the same time adding to the relevancy of the museum's message. This is not to say the heritage of Tarnów should be seen as inferior, but rather as the museum's way of coping with the prestige and glory represented by the exhibits of the $17^{\text {th }}$ and $18^{\text {th }}$ centuries, which at some points seems to overwhelm the other possible aspects of the museum's storytelling.

In order to set the perspective for the analysis, a short tour of the exhibition of the Town Hall is proposed. This is the usual way of getting to know the museum's collection and it allows us to sketch a fragmented and experience driven way of sightseeing. It is an important, but surprisingly often overlooked fact, that visitors are not very interested in the museum itself, but rather in the heritages presented (and interpreted) by them. Considering this, a visit oriented museum analyses (as opposed to collection analyses) could be seen as reflecting the majority of visitors' experiences influenced by the exhibitions. At the same time, it should be said that the museum's activities may influence many actors, as the museum's authority of safeguarding the past of the town and the region is very strong indeed and the museum's staff act as experts in a number of public and private bodies. Nevertheless, it is the exhibitions (and the sites themselves) which remain the most important elements of the museums' impact and visiting them in person provides the opportunity to learn the most about the region and the district of Tarnów.

It may be worthwhile to start the visit in the last (and extra) point of a regular sightseeing, that is to climb the tower where a magnificent panorama of the town can be admired, as well as the tower clock mechanism which is presented to all who walk up the stairs. The clock is still operationall, making it unique, but also significantly confirms the spirit of continuity: this is the same clock that gave rhythms to the city life centuries ago and the bell has constantly kept Tarnów citizens tuned to the passing of time. The rigid monotony of the tower clock gives a good background to the main narrative of the exhibition: people lived and passed away, and those who want to remember them inscribe themselves in the same long duration history told as a composition of individual biographies, as well as the social movements and political shifts both presented in the exhibition as somehow unavoidable and external to individual lives.

Next to the clock tower mechanism and protected by glass is a small archeological exhibition which immerses the town's history in a narrative more ancient than the historical one: there is a mammoth tusk, excavated locally and there to signify the pre- 
history of the town. Its presentation, next to the clock mechanism, makes the temporal context even more profound, although it must be mentioned that the presentation of mammoth's teeth and tusks is not unusual for smaller and larger museums. It is not really clearly explained whether presenting mammoth's remains should symbolize the times before human memory can grasp it or rather it is used to testify to the skills of the archeologists, at the same time adding to the image of the museum as shelter for everything that may have value because it is very old. ${ }^{56}$ Nevertheless, establishing such a temporal context makes the city's foundational myth more significant: it makes it clear that the story is very long.

Coming back to the regular sightseeing program, before visitors set off to see the main collections of the Town Hall (the art and crafts of $17^{\text {th }}$ century Poland) they are shown some photographs in the lobby of the Gumniska property of the Sanguszko family, who - as the guide says - ruled and owned most of the city. The collection of images comprises conventional noble class possessions such as stables, parks or parts of manors and mansions. The legacy of the Sanguszko in Tarnów has somehow been retained to the present (2017): a photograph of the prince and princess visiting the museum in the present day can be seen on the upper floor, next to the china and silverware collection which in fact mostly belonged to the family as well and had been rescued right after World War II from their palace. The decision to secure the objects was a consequence of the nationalization act which acquired valuable objects and items that would be the property of the state from then on. It is rather hard, however, to connect them so that they form a convincing message about the origins of the collection. On the contrary, the photos represent the fact that some unknown property creates a form of postmemor $y^{57}$ to be freely decoded by visitors but one which is not very well explained to them.

The main room of the Town Hall and the museum itself is the former audience room. It is the largest and its former function is barely noticeable due to the concept of the design: a large collection of portraits is exhibited on the walls in such a way that they dominate the whole of the interior, leaving its original function mostly to the imagination of the visitors, while the figures and faces of people in the portraits tend to command their attention. The discrepancy between the original function of the space and decorating it with aristocratic images is significant, especially as this seems to be the most civil space in the whole of Tarnów. On the walls there are dozens of portraits but there are not many explanations as to who the portrayed people were. However, such a silence has interesting consequences: visitors are urged to interpret the portraits for themselves and, despite not knowing much (or anything at all) about the individuals presented in the pictures, they somehow 'face' them and look into their eyes, trying to

56 In fact, the Tarnów Museum records its efforts to construct meaningful collection from the start, for example a collection of butterflies, offered as a gift to the museum, was decided to be irrelevant and did not enter the collection. Ibid., p. 8.

57 The term was introduced by Marianne Hirsch who examined meaning making processes in relation to photographs connected with pre-Holocaust and Holocaust era. M. Hirsch, Family. Photography, Narrative and Postmemory, Cambridge-London 1997. 
anchor their attention to any detail which might be recognized without expert knowledge. Visitors notice women, children and men, all dressed elegantly and looking at the viewers from some remote estate that they used to live in. Exhibiting the whole collection of portraits raises a number of questions concerning their origin, artistic quality or merely who they present, still the main impression visitors may get is very general, although the collection can be also read as an introduction to other parts of the exhibition. Many of the portraits are classified as 'Sarmatian', recalling the concept of the Sarmatian tradition which was believed by the Polish gentry to have provided the roots of their own families (and the Polish nation) and certainly inspired the costumes of wealthy Poles in the $17^{\text {th }}$ and $18^{\text {th }}$ centuries. The clothes of the portrayed people are very richly ornamented and bear witness to the wealth on display.

The portrait collection compliments the narrative of the magnificent weaponry collection, which is presented on the ground floor of the town hall, next to the photos in the lobby. For non-expert audiences, the exhibits are difficult to interpret, as first of all the labels do not provide support in that matter, being 'museologically' structured while the textual descriptions to be read on the walls are far too long and unattractively presented in small fonts on a grey background. It is mostly the guide's personal skills, attitude and knowledge that can awake the meanings locked in the exhibits. The most crucial fact about the weaponry, as well as most of the silverware collection, is that it was bought by the Sanguszko family already as a collection of antiques, to be later enriched by further purchases. This means that what the objects illustrate is in fact not the everyday life of Tarnów (or the region) at all but rather a concept for the antiques collection of Polish gentry. This reveals another aspect as well: the objects were not only already old when they were acquired but also represent symbolic (non-practical) value, adding to the prestige of family estate which they had decorated.

Quite surprisingly, as it has been already stated, the whole storytelling of the Town Hall exhibition could be read as exemplifying the glorious past of Tarnów, as more than 'just a provincial town', when it is perhaps truer that the exhibition relates in fact more to the lifestyle of the gentry, presented here as representative of the whole of the city's past. The weapons, for instance, are interpreted first of all as elements of lifestyle, as some of them had been used for hunting. The diversity of the exhibited objects may reflect the ways of spending free time as much as the skills of craftsmen, but probably should not be presented as representative for (any) period.

The interesting part of the collection, and at the same time of the story told in the museum, is connected with the siege of Vienna (1683). It is recalled with exhibits such as a mobile tent to be set in the battlefield or a shoe attributed to Queen Marysieńka, wife to Jan III Sobieski, the heroic king who is presented as defending Europe from an Islamic invasion. His achievement, as visitors learn from the guide, would not have been possible without the bravery and sacrifice of Polish soldiers, many of whom originated from the region around Tarnów. The victory of Vienna is described as a civilizational act of domination, a historical moment of Poland's significance in European history. This plot is developed later on in the exhibition, when an interpretation of the portraits is offered by the guide. Visitors may learn about one of the favorite and most 
popular Polish myths of origin, namely the Sarmatian, and the myth is not deconstructed in the guide's narrative but rather emphasized as still having a profound impact on Polish national identity. Poles (and not only Tarnów inhabitants) are presented as the brave defenders of Christian civilization and Europe. Again, the bravery, rich imagination and effectiveness of Poles, for whom the local representation is given with the portraits, are highlighted. The feeling of pride due to belonging to a community of brave men of honor is promoted in the guide's storytelling and, by setting the context of the glorious past together with the weaving together of the story of continuity, visitors may feel invited to share in the legacy presented therein. Through this story, Europe is presented as an integral entity which needs to be defended from invaders and Poles are entitled to do it, especially as the inheritors of the Sarmatians.

Striving to build correspondences between Europe, Poland and the city of Tarnów, it is presented as a good example of community where both local and national patriotism have been effectively cultivated. Most unfortunately the narrative is exclusively in terms of one class: history is presented as a construct shaped by noble families and social diversity of the past is hardly ever mentioned. This drawback may be justified by the fact that in other branches of the museum, other versions of story are told, but the fact remains that the narrative of the Town Hall exhibition promotes the aristocratic legacy of the past.

As to the collection itself, the impression that visitors may get is the complexity of objects and probable codes of behavior which can be deduced from the objects. It is in fact very significant that the image of the past created on the exhibition is based on weaponry, silverware and china, portraits of noblemen and some pieces of armor and related objects of war. Hunting, battles, parties and romance seem to make up the content of the past, all spanning the period from the times of the mammoths until the symbolic collapse of Tarnów, an incident presented as having been caused mainly by external conditions of a historical, social and political nature. But Tarnów reclaims its golden age in its museum's presentation, where inferiority complexes may be healed and the civilizational narrative can be effectively spread.

The PUDDING model proposed in the first part of this article stipulates several qualities that by means of their relation to European values can function as indicators of Europeanization in museums. In the following section we would like to examine to what extent these qualities are to be detected in the museum in Tarnów. Progress is the first one on the list, and the Town Hall exhibition, which certainly follows the linear time model in most of its storytelling, seems to escape the simple story of progress and to instead provide visitors with a kind of niche view of the passing of time, not leading anywhere in terms of civilizational progress, but rather establishing important symbolic resources for the identities: local, regional and national. There are some elements of weaponry presented, however, which may be interpreted as very elaborate and highly complicated, and thus technical progress can be somehow read in them yet it is the spirit of past glory that feeds the dominant narrative much more than the linearity of civilizational progress. Visitors may actually get the impression that the golden age of Tarnów and the region should be preserved in the museum, but since no literary recre- 
ation of the past is possible, the museum can be regarded as constituting a shelter for it, a symbolic treasury that can be used for meaning-making purposes. In other words, the linearity of the story is woven here to set a strong mythological setting for the myth of origin, but there may be a feeling of discontinuity too because visitors don't learn much about Tarnów in the years after the end of the private city era.

The interpretation of utility may also be interesting since the objects on display relate most of all to their symbolic meaning, as they stand for the wealth of the noble classes. In other branches of the museum, however, many everyday objects used by the poorer people (significantly in the Roma exhibition) are explained as having very practical uses. This supports the notion of non-technical objects of prestige, such as the silverware collection, strengthening the image of those who did not possess many objects, but those that were in their possession had to be practical. In this perspective, establishing the interpretive framework for heritage as such seems to define it as a class driven phenomenon belonging to the rich. This is also why it is extremely important to have a look at other branches of the museum, where various heritages are presented, leaving the one of prestige and gentry as one of many. Still, this is the one that sets the scene and this is the one presented as most significant for identity formation today. A museum, with all its heritage on display, seems to have vague correspondences to local identity construction, as the content of it is representative for one family, but in fact it may be very useful because the storytelling adds up to the national mythology with the message of Tarnów as relevant. The only problem with this may be that the symbolic capital gathered and presented here is hard to transform into social capital.

The issue of dignity may also be interpreted given the portraits and objects of the gentry: as ancestors are presented with an outlook of grace and honor, provided mostly by the distance between the past and the present. The museum follows a traditional, semi-feudal way of representing the past, with the emphasis on luxury and which itself adds to the prestigious and symbolic potential of the exhibition, at the same time keeping it far from the hybrid and diverse 'reality' of the past.

Diversity, another aspect of the PUDDING framework, is limited by the representation of only one class in the exhibition, but it should be pointed out that in terms of reaching out to new audiences, the museum can boast some successes such as cooperation with the local prison and schools. Programs tailored to suit the needs of prisoners do not reflect the content of the Town Hall exhibition, but are much more focused on World War II and the history of Jews in the region. There have been, however, some 'museum meetings' held at the museum, where various stories from $17^{\text {th }}$ century Poland were mentioned, with special regard to weaponry and wars. ${ }^{58}$ Schools and other educational institutions are offered a special, discounted museum visit (Pl. bon kultury) which is subsidized by the Małopolska Marshal's Office as a result of an open competition. The workshops and museum classes are well received, providing a light introduction to history, narrated in a semi theatrical way, creating a good form of 'edutainment'. It is hard to admit that the past is presented in its diversity, as the presentation is limited

58 As recalled by Janusz Kozioł in the interview. 
to the collection related to one social class and not many interpretative perspectives are included, either.

One could see, however, that narrativity - the next framework element - is a real component of the exhibition. The story of the past is told with vivid images and many narrative strategies are used by the guides, including demonstrations of objects or biographical stories. The main characteristics of the storytelling, however, may be defined by its mythological function, which in this case might be seen as safeguarding the images and the values of the past. In their narratives, guides would rather stress the differences between contemporaneity and the past, without clearly stated similarities. Europe from these stories appears to be a different domain than the one of today, with no links to the political situation of today.

There is one more aspect of narrativity which should be revealed here and it may be interpreted as a form of utility, too. The setting of the Town Hall tower has some reputation as the most romantic site of Tarnów and is known as a perfect place for proposals. It is hard to say whether the dramatic scenery overlooking the town, the history of the building or the treasure it shelters support this choice of place, but the museum supports this romantic use of its site with some public consequences. ${ }^{59}$

In terms of governance, the last part of the PUDDING model, the striking absence of civil history in the Town Hall may be read as reducing heritage to nobility, a rather non-democratic way of storytelling about the past. It needs to be added, however, that in the guide's comments there is some irony about the old time heroes, too, still due to the limited time of a museum visit, the complex and critical part of the story gets dominated by the more direct, mythical like one. It is challenging for visitors to fully appreciate the richness of what can be told in the museum, as the visit is hardly ever participative, although there are some opportunities for the visitors to try the old cloths, armor or weapon (only available with the guided visit).

In general terms, the democratization of heritage is not an easily recognizable asset of Tarnów Town Hall, although it is quite unfair to judge the whole museum solely on the basis of the highlights presented there. Yet, as has been already said, many visitors would choose this branch as the most representative one, so it should be given special attention even if it is not representative of the other museum branches. As already stated, the exhibition highlights the presented objects as symbolic resources and they should be treated as important in constructing reference frameworks for identity, and finding the concept of Europe is not difficult at all: being juxtaposed to Islam, Europe is told in accordance with the Polish national tradition, where romanticism often takes over historiography. Because the collection comprises objects from the late $16^{\text {th }}$ and $18^{\text {th }}$ centuries, the main story illustrated with exhibits is the Sarmatian one, with the figure of Poles as a noble nation of proud heroes, who appreciate life but sometimes can be misguided by their fantasy. Establishing such a mythical reference was apparently regarded as being fake from the outset but the fiction that Poles had originated from an

59 As demonstrated in several interviews, the actual lack of proper marketing and public relations staff in the museum is critical for the potential impact of the museum. 
ancient tribe was widely accepted amongst the gentry. The game of the popularization of the myth, both real (in social terms) and false (historically) is still being played today by the institution involved in the interpretation of both Polish and local tradition.

Throughout the whole narrative the construct of Sarmatians as ancestors to contemporary Poles is ubiquitous. Their story is told with a sense of dignity: as politically and economically important, they not only influence but in fact co-author history. The main theme for the exhibition might be formulated as 'the old times of the civilization we live in today', and the Sarmatians are shown as significant citizens of Europe. Yet the dignity and individualism strongly narrated in the exhibition are presented without any social perspective of those groups and people who could not have benefited from their wealth. This makes the exhibition far from the accepted standards of democracy and inclusion, but strengthens its mythical symbolic potential. A silver sugar box exhibited behind glass is a good illustration of this: the exhibit is made of silver and has a key hole which is explained by the guide as protecting the sugar from being stolen by servants.

\section{COMPARATIVE REMARKS AND CONCLUSIONS}

The use of the PUDDING framework allows us to draw some comparative conclusions regarding the Europeanization of heritage in the two museums scrutinized here. The seven qualities serving as indicators of this process and summarized in the acronym are present in our cases to considerably varying degrees.

As demonstrated in the analysis, the idea of PROGRESS is clearly visible and even acclaimed in Kulturen in Lund, where the linearly structured narratives emphasize continuity in civilizational advancement and express the pride of the local society of being part of this development. This cannot be said about the Tarnów exhibition, in which progress is just indicated in the linearity of the narrative which more or less ends in the time of the Polish Noble Republic ( $16^{\text {th }}-17^{\text {th }}$ century), which is presented as a golden age and source of local and national pride.

As to the second element of the PUDDING model - UTILITY - the contrast is even greater. While the museum in Tarnów seems to have as its only goal the preservation of heritage objects and presenting them to the public so they can be admired and enjoyed, the museum in Lund aims primarily to pit its collections in the service of education and research. Additionally, Kulturen works purposefully with its public mission by opening its doors for social, cultural and scientific events. In other words, Kulturen fully embraces utility as a quality for modern European heritage.

The next quality - DIGNITY - can be traced in both museums, but it is articulated in very different ways. The exhibition in Tarnów has its focus on noble individuals and families. Dignity emanates from them while, at the same time through the metonymic operation in the presented narrative, they give dignity to the town of Tarnów and the whole Polish nation. In Kulturen, the nobility is marginally present and there is also much less emphasis on concrete individuals. Dignity mainly comes forward in repre- 
sentations of the hard and creative work of people representing different social classes. It is also visible in efforts to dignify the previously or currently marginalized and socially stigmatized groups such as Roma.

In terms of DIVERSITY and INCLUSION, the exhibition in Tarnów, as shown above, is extremely limited, while Kulturen is very keen to display social diversity, include different interpretative perspectives and work to increase participation and accessibility for people with different social and ethnic backgrounds, ages and even handicaps. In recent years the Swedish museum has even begun to work with the legacy of migration which was previously absent in the museum's exhibitions.

The sixth quality in the PUDDING model - NARRATIVITY - is central for the Tarnów Museum while less prominent in the museum in Lund. The main reason is probably that Tarnów presents a visitor with one, impressive, vivid and detailed grand narrative about the past of the Polish nobility and the Polish nation, while Lund offers a multitude of small, local and regional narratives that compete with each other for the attention of the visitor. Moreover, the narrative in Tarnów is embedded in the aura of an old Saramatian myth which has the potential to kindle fantasy and playfulness, while the narratives in Lund are rather down-to-earth and educationally oriented. It is also noteworthy that the narrative presented in Tarnów supports local identity as much as the national one, while regional belonging is almost invisible. This is in contrast to Kulturen, which focuses very much on stories supporting regional and local identities, leaving the national dimension almost totally aside. Another important difference between the two museums' approach to narrativity is their different temporal dimensions. The narrative in Tarnów's Town Hall is wholly oriented to the past and it indulges almost nostalgically in the lost national glory of the past. The narratives in Lund, on the contrary, are very much oriented towards the present and even to the future. They are often constructed in response to the societal challenges of the present, such as, for example, the growth in racism and xenophobia or the challenges of mass migration to Europe.

These narrative features characteristic of the respective museum can explain to some extent the difference between them in regard to the last element in our acronym - GOVERnAnCE. The Tarnów Museum seems to lack relevancy in terms of modern governance and democracy. In the exhibition, the distance between the past, which remains a powerful symbolic resource, and the present, is so immense that it is challenging for the visitors to refer to it and use it in their life for other ways than just pure pleasure. Kulturen, on the other hand, works very methodically in promoting such democratic values as participation, inclusion, tolerance and equality, both in its exhibitions as well in other activities: outreach, contact with stakeholders and the organization of social and cultural events. The museum shows considerable engagement in social and political life.

To conclude, our analysis of Kulturen and the Town Hall Museum in Tarnów with the help of the PUDDING model allows us to draw some conclusions as to the scope of the Europeanization of heritage in the two museums. It can be stated that the heritage work conducted at Kulturen in Lund is very much in accordance with the policies and 
visions of heritage promoted by the EU and supported by the ideas of new museology. In its exhibits and activities, the museum displays all seven qualities identified by us as crucial for current European heritage work. This cannot be said about the museum in Tarnów, where such elements as progress and utility are visible but far from obvious. Diversity and inclusion, not to mention governance including participation and democracy, are practically wholly absent.

However, in comparing the two museums we can notice an interesting paradox. While the Swedish museum, unlike the Polish one, works very much in accordance with current European models, it is seldom explicit in its references to Europe and never to the EU. Europe remains largely invisible, despite the international connections of the locality being featured in the exhibitions. Moreover, as it transpired in the interviews, the museum staff at Kulturen does not perceive their work as being affected by the EU's policies in any way. At best they agree that if this is the case, then the influence is imperceptible, perhaps because it is channeled via regional and municipal institutions. It is the local authorities that urge the museum to fulfill some tasks which may reflect the goals of the EU's policies and the values promoted by the Union, such as democracy or respect for minority rights and human rights. However, according to our informants at Kulturen, these goals and values have been important for the museum for many years, even before the Swedish accession to the EU. The only clearly later additions are the interest in memorializing the Holocaust and the victims of Nazism that found refuge in Sweden, and the attention paid to ethnic diversity, especially that resulting from migration. These two elements are recognized by our informants as a possible outcome of Europeanization. However, it is noteworthy, that the Europeanization process in this context is apprehended by them not primarily as a vertical top-down movement, a result of the EU-directives, but rather as a horizontal movement, an outcome of intensified transnational exchange of ideas and mutual influences coming in the wake of increased mobility, migrations and closer cooperation.

In contrast to Lund, Europe as a concept is visible and referred to in the Tarnów Museum. Yet it is not articulated by the implementation of certain qualities referring to the specific values described above, but by giving Europe a substantial place in the narrative. In that narrative Europe as such is mainly a mythical domain of the past which is referred to because it has been safeguarded by the Poles. In turn, they are presented as always having been loyal to both their own nation and Christianity and thus, by extension, to Christian Europe. Locality is constructed in a very significant way, too, being an important component of the larger community of nation and then, in the next step, of Europe. Thus, Europe is present and seems to be highly valued (worth fighting for), but as a myth and arena where Polish bravery and other virtues can be displayed, not as a currently existing entity with concrete politics and visions. In our view, this interpretation of Europe does not offer museum visitors any tools for a better understanding of the current world and for making meaningful correspondences with the knowledge they already have. Consequently, it could be argued that the heritage presented in Tarnów's Town Hall is European, in the traditional and literal sense of the word, but 
not Europeanized in terms of the adoption of ideas of modern European museology and ideas about the heritage promoted by the EU.

The framework of PUDDING applied above was developed in order to support research carried out in museums, with a special emphasis on the Europeanization of heritage. The main idea was to help in structuring the analysis of the otherwise very complex matter of museums' exhibitions, activities, programs, outreach and all practices that could be considered in their analysis. The PUDDING framework does not include all aspects of a museums' functioning, but our analysis above proves, in our view, that it is effective in tracing Europeanization processes in museums, which are otherwise rather abstract, complex and not easy to capture. It should also be noted that as a tool it need not be applied in every fragment, although it is useful to bear in mind the interconnections between all seven elements. We hope that it will be useful for further research.

\section{BIBLIOGRAPHY}

Anderson B., Imagined Communities. Reflections on the Origin and Spread of Nationalism, London 1983.

Anderson G. (ed.), Reinventing the Museum. Historical and Contemporary Perspectives on the Paradigm Shift, New York 2004.

Att överleva. Röster frän Ravensbrück. En lärarhandledning, Kulturen 2006, at <http://www. kulturen.com/wp-content/uploads/2016/12/Ravensbruck_Lararhandledning.pdf $>$.

Bennett T., The Birth of the Museum. History, Theory, Politics, London-New York 1995.

Bennett T., "Civic Seeing: Museums and the Organisation of Vision", in S. MacDonald (ed.), A Companion to Museum Studies, Hoboken 2011.

Bennett T., "Exhibition, Difference, and the Logic of Culture", in I. Karp, C. Kratz, L. Szwaja (eds.), Museum Frictions. Public Cultures/Global Transformations, Durham 2006.

Brett D., The Construction of Heritage, Cork 1996.

Calligaro O., Negotiating Europe. EU Promotion of Europeanness since the 1950s, New York 2013.

Clair J., Malaise dans les musées, Paris 2007.

Connerton P., How Societies Remember, Cambridge 1989.

Delanty G., The Cosmopolitan Imagination. The Renewal of Critical Social Theory, Cambridge 2009.

"A Europe of rights and values", Treaty of Lisbon, at <http://ec.europa.eu/archives/lisbon_ treaty/glance/rights_values/index_en.htm>.

European Commission, Communication from the Commission to the European Parliament, the Council, the European Economic and Social Committee and the Committee of the Regions "An EU Framework for National Roma Integration Strategies up to 2020", Brussels, 5 April 2011, 
$\operatorname{COM}(2011) 173$ final, at <http://ec.europa.eu/transparency/regdoc/rep/1/2011/EN/12011-173-EN-F1-1.Pdf>.

European Commission, Mapping of Cultural Heritage actions in European Union policies, programmes and activities, August 2017, at <http://ec.europa.eu/assets/eac/culture/library/ reports/2014-heritage-mapping_en.pdf $>$.

Föreningens stadgar, Kulturen, at <https://www.kulturen.com/om-kulturen/vardegrundvision-och-uppdrag/foreningens-stadgar/>.

Frykman J., Löfgren O., Den kultiverade människan, Lund 1979.

Hajduk J. et al., Lokalne muzeum w globalnym świecie. Poradnik praktyczny, Kraków 2013.

Halbwachs M., La mémoire collective, Paris 1939.

Hirsch M., Family. Photography, Narrative and Postmemory, Cambridge-London 1997.

Hobsbawm E., Ranger T. (eds.), The Invention of Tradition, Cambridge 1983.

Kołodziej M. et al., "Historia Muzeum Okręgowego w Tarnowie. History of Tarnów Museum”, in 80 lat Muzeum w Tarnowie. 80 Years of Museum in Tarnów, Tarnów 2007.

Kommunalt uppdrag, Kulturen, at <https://www.kulturen.com/om-kulturen/vardegrundvision-och-uppdrag/kommunalt-uppdrag/>.

Kowalski K., Törnquist-Plewa B., "Heritage and Memory in a Changing Europe, Introductory Remarks", in K. Kowalski, B. Törnquist-Plewa (eds.), The Europeanization of Heritage and Memories in Poland and Sweden, Kraków 2016.

Kulturens värdegrund (Kulturen's Principal Values), Kulturen, at <http://www.kulturen.com/ wp-content/uploads/2017/01/Kulturens-v\%C3\%A4rdegrund.pdf $>$.

Kulturens verksambetsberättelse 2015 (Kulturen's annual report from 2015), at <http://online. pubhtml5.com/lbgr/etzh/\#p=4>.

Lowenthal D., The Past is a Foreign Country, Cambridge-New York 1985.

Lord B., "Foucault's Museum: Difference, Representation and Genealogy", Museum and Society, vol. 4, no. 1 (2006).

Luke T.W., Museum Politics. Power Plays at the Exhibition, Minneapolis 2002.

Magnusson Staaf B., “The White Buses Creating Remembrance of the Second Word War in Sweden", in K. Kowalski, B. Törnquist-Plewa (eds.), The Europeanization of Heritage and Memories in Poland and Sweden, Kraków 2016.

Muzeum Okręgowe w Tarnowie (Tarnów Museum), at <http://www.muzeum.Tarnów.pl/>.

"New Publication: Museums, Migrations and Cultural Diversity", NEMO, 30 May 2016, at <http://www.ne-mo.org/news/article/nc/1/nemo/new-publication-museums-migrantsand-cultural-diversity $>$.

O’Neill M., "Enlightenment Museums: Universal or Merely Global?", Museum and Society, vol. 2, no. 3 (2004).

Oredsson S., Lunds universitet under andra världskriget - motsättningar, debatter och hjälpinsatser, Lund 1996.

Piekarska-Duraj Ł., "Democratization as an Aspect of Heritage Europeanization. The Museum Triangle", in K. Kowalski, B. Törnquist-Plewa (eds.), The Europeanization of Heritage and Memories in Poland and Sweden, Kraków 2016.

Piotrowski M. (ed.), Pamiętnik V Zjazdu Delegatów Związku Muzeów w Polsce odbytego w Tarnowie w dn. 12-13 czerwca 1930, Kraków 1930. 
Regionalt uppdrag, Kulturen, at <https://www.kulturen.com/om-kulturen/vardegrund-visionoch-uppdrag/regionalt-uppdrag/>.

Sandell R. (ed.), Museums, Society, Inequality, London 2002.

Sassatelli M., Becoming Europeans. Cultural Identity and Cultural Policies, New York 2009.

Schuman R., Pour l'Europe, Paris 2000.

Sherman D.J., Museums and Difference, Bloomington 2008.

Sherman D.J., Rogoff I. (eds.), Museum Culture. Histories, Discourses, Spectacles, Minneapolis 1994.

Shore C., "Inventing Homo Europaeus: The Cultural Politics of European Integration", Ethnologia Europaea. Journal of European Ethnology, vol. 29, no. 2 (1999).

Sierp A., History, Memory, and Trans-European Identity. Unifying Divisions, New York-London 2014.

Simon N., The Participatory Museum, Santa Cruz 2010.

Tilden F., Interpreting our Heritage, Chapel Hill 2008 (1947).

Tinning K., "To Survive Ravensbrück: Considerations on Museum Pedagogy and the Passing on of Holocaust Remembrance", Museum \& Society, vol. 14, no. 2 (2016), at <https://www2. le.ac.uk/departments/museumstudies/museumsociety/documents/volumes/tinning >.

Törnquist-Plewa B., "The Europeanization of the Memory and Heritage of the Second World War and the Holocaust in Sweden", in K. Kowalski, B. Törnquist-Plewa (eds.), The Europeanization of Heritage and Memories in Poland and Sweden, Kraków 2016.

To Survive - Voices from Ravensbrück, Kulturen, at <http://ravensbruck.kulturen.com/English/ r1.htm\#>.

Värdegrund, vision och uppdrag (Statues for Cultural-Historical Association for Southern Sweden (Kulturhistoriska föreningen för södra Sverige)), Kulturen, at <https://www.kulturen. com/om-kulturen/vardegrund-vision-och-uppdrag/>.

Världen på Kulturen, Kulturen, at <http://www.kulturen.com/utstallningar/kommandeutstallningar/varlden-pa-kulturen/>.

Vergo P. (ed.), The New Museology, London 1989.

\section{Interviews with}

Anki Dahlin, director at Kulturen, 5 April 2017.

Johan Hovfdahl, museum communicator at Kulturen, 15 March 2017.

Janusz Kozioł, deputy director at the Tarnów Museum, 3 June 2017.

Björn Magnusson Staaf, former manager at Kulturen, 24 March 2017.

Anonymous content analysis questionnaire conducted during "Local Museum in a Global World" action research project, conducted in October 2013 at the Tarnów Museum (J. Hajduk et al., Lokalne muzeum w globalnym świecie. Poradnik praktyczny, Kraków 2013). 
Łucja PIEKARSKA-DURAJ holds an MA in European Studies (2002) and a PhD in sociology (2013) both received from the Jagiellonian University. She is currently affiliated with the Institute of European Studies at the Jagiellonian University. She is a social anthropologist, interpretive heritage trainer and cultural manager. As a researcher, she is mainly interested in relations between social memory, heritage and identity, especially in the domain of museums. As a heritage consultant she promotes interpretive and democratic museology. She specialises in storytelling for museums and the support for brand management strategies. She has co-authored a manual for interpretive museology Lokalne muzeum w globalnym świecie. Poradnik praktyczny [Local museum in a global world] (written with Joanna Hajduk, Sebastian Wacięga, Piotr Idziak, Kraków 2013) as well as a number of museum exhibitions and projects (e.g. dzieto-dziatka, Kraków Ethnografical Museum, 2010; "Wirtualne muzea Małopolski", 2009-2014; "Muzeobranie", 2004-2006). After a decade of museum activism, she joined the UNESCO Chair for Holocaust Education at the Jagiellonian University (2016).

Barbara TÖRNQUIST-PLEWA is a professor of Eastern and Central European Studies at Lund University in Sweden. In the years 2005-2017 she was the head of the Centre for European Studies in Lund. Her main research interests are nationalism, identity and collective memories in Eastern and Central Europe, but she has also published on Polish-Swedish cultural relations. She has participated in many international research projects and, most recently, she was the leader of the European research network "In Search for Transcultural Memory in Europe" (financed by the EU's COST-programme 2012-2016). Currently she is co-leader of the International Research Training Group "Baltic - Borderlands", run by the universities in Greifswald, Tartu and Lund since 2009. Her international experience also includes visiting fellowships at universities in Warsaw (2001), Berkeley (2003) and Stanford (2013) and lecturing visits at the National University of Malaysia (2014) and the Tokyo University of Foreign Studies (2016). She is the author and editor of a number of books and articles in English, Swedish and Polish. The latest are: The Twentieth Century in European Memory (ed. with Tea Sindbaek Andersen, Amsterdam 2017), Disputed Memory. Emotions and Memory Politics in Central, Eastern and South-Eastern Europe (ed. with Tea Sindbaek Andersen, Berlin-Boston 2016), Whose Memory? Which Future? Remembering Ethnic Cleansing Beyond and Lost Cultural Diversity in Eastern, Central and Southeastern Europe (New York-London 2016) and The Europeanization of Heritage and Memories in Poland and Sweden (ed. with Krzyszof Kowalski, Kraków 2016). 